\title{
DÜBLIN
}

Technological University Dublin

ARROW@TU Dublin

2015-01-19

\section{Tour Guides and the Mediation of Difficult Memories: the Case of Dublin Castle, Ireland}

\author{
Bernadette Quinn \\ Technological University Dublin, bernadette.quinn@tudublin.ie \\ Theresa Ryan \\ Technological University Dublin, theresa.ryan@tudublin.ie
}

Follow this and additional works at: https://arrow.tudublin.ie/tfschhmtart

Part of the Hospitality Administration and Management Commons, and the Tourism and Travel Commons

\section{Recommended Citation}

Bernadette Quinn \& Theresa Ryan (2016) Tour Guides and the mediation of difficult memories: the case of Dublin Castle, Ireland, Current Issues in Tourism, 19:4, 322-337, DOI: 10.1080/13683500.2014.1001727

This Article is brought to you for free and open access by the School of Tourism \& Hospitality Management at ARROW@TU Dublin. It has been accepted for inclusion in Articles by an authorized administrator of ARROW@TU Dublin. For more information, please contact arrow.admin@tudublin.ie, aisling.coyne@tudublin.ie, gerard.connolly@tudublin.ie.

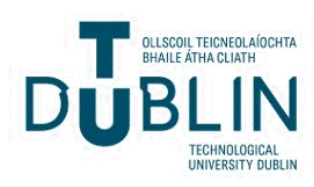




\title{
Tour Guides and the mediation of difficult memories: the case of Dublin Castle, Ireland
}

\author{
Bernadette Quinn* and Theresa Ryan
}

(Received 21 May 2014; accepted 18 December 2014)

This research seeks to furthering understandings of how Tour Guides interpret memories at heritage sites when the memories at issue are difficult yet subtle and not always apparent to tourists. Specifically, it explores how Dublin Castle, formerly the seat of British rule in Ireland, is captured in narratives presented to tourists that often include Britons. Representing the site is made challenging because some visitors have little knowledge of the site's history, while others are well informed and hold strong political views. The findings show that Guides select largely depoliticized narratives, strongly influenced by their personal interests and experiences. Some hint at underlying tensions that only tourists alert to the complexities of the site might capture. Dominant narratives can be challenged by tourists with an interest in, or allegiance to, particular historical or political beliefs, leading to emotional engagements. Some tourists, unaware of the complexities of the site, can encounter a more multi-layered and complex experience than perhaps envisaged. The study affirms the co-production evident in Tour Guiding narratives and points to the need for further research into how the variously empowered agencies of both the Guide and the tourist produce a constant shifting and re-working of memory.

Keywords: Tour Guides and operators; interpretation; tourist agency; co-production; heritage sites; Ireland

\section{Introduction}

The role played by the Tour Guide in tourism contexts seems to be attracting increasing research attention of late. As Dahles (2002) notes, the Tour Guide is variously understood as a purveyor of information (Holloway, 1981), a translator of culture (Cohen, 1985; Salazar, 2005) and as something of a mediator 'conveying information, offering explanations and developing narratives' (Dahles, 2002, p. 783). Over time, the complexity of the tour guiding role has become ever more apparent. It is now understood that Guides simultaneously enact a range of roles including that of leader, educator, public relations representative, host and conduit (Pond, 1993). It is further understood that the performance of these roles is not unproblematically determined solely by the Guide's intent but is shaped by a variety of influences wrought, for example, by government agencies, destination managers and by tourists themselves.

Understanding the role of the Tour Guide becomes more difficult when viewed in tourism contexts where interpreting meaning is open to negotiation and contestation. These challenges are even more intensified when the site in question and its troubled and 
frequently contested past is not immediately apparent to all those who visit. This is the arena within which this paper locates its enquiries. It is concerned with Tour Guides' interpretation and representation of a site that, while having a complex and unsettling past, is not overtly associated with difficult memories by all those who visit. The empirical research underpinning the paper investigates colonial memories constructed and represented to tourists at Dublin Castle. The Castle is an important visitor attraction in a city where a significant majority of tourists come from the country's former colonizer, Britain. Many visitors hold few pre-conceived views about the Castle. Others are very knowledgeable about the Irish history and often have strongly held political views and opinions on the narrative that should be conveyed.

The paper begins by reviewing the literature on memory, heritage and the role played by the Tour Guide. A key research question concerns the extent to which the Tour Guide ultimately determines what is remembered and represented to the tourist. Simultaneously, cognizant of the growing attention being paid to the co-production of tourist experiences (Larsen \& Widtfeldt Meged, 2013; Salazar, 2005; Widtfeldt Meged, 2010), the paper queries the extent to which the tourist is active in co-producing the emerging narratives. The study employs an interpretivist approach, gathering qualitative data through interviews with Guides and covert participation observation of guided tours.

\section{Difficult memories and heritage sites}

Like language and culture, history plays a significant role in how nations are imagined (Zuelow, 2009). A shared past provides a nation with legitimacy (Zuelow, 2009). There can be no sense of identity for nations or indeed for individuals without remembering (McBride, 2001), as a rich legacy of memories is fundamental to the existence of a nation (Renan, 1990, cited in McBride, 2001). Memory, therefore, is integral to the formation of identity. As Said (2000) explains, questions of identity, nationalism, power and authority are touched very significantly by memory and its representation. The formation of narrative and the process of remembering are not straightforward, as the representation of history through narrative is strongly informed by decisions (whether conscious or unconscious) as to what is remembered. Memories are both particular and universal (Hoelscher \& Alderman, 2004) and are strongly influenced by the act of forgetting or 'forgetting to remember' (Devan \& Heng, 1994, p. 267). Indeed, memory selectively eliminates undesirable aspects from the past, highlights favoured events and renders history 'tidy and suitable' (Lowenthal, 1975, pp. 27-28, cited in Chang \& Huang, 2005). Alderman (2010, p. 90) echoes this point, explaining that 'what is defined as memorable or historically significant is open to social control, contest, and negotiation, a process that constitutes the politics of memory'. Furthermore, the way in which history is evoked and collectively negotiated may differ, as remembering and collective memory is not always consistent and shared. Collective memory is both unpredictable and central to the maintenance and contestation of political identity (Hoelscher \& Alderman, 2004). Agreement that a nation has a common past is one thing; however, 'it is another thing altogether to agree on precisely what that past was' (Zuelow, 2009, p. 136). Accordingly, representation of the past is likely to be selective, with Chang and Huang (2005) pointing out that memories and decisions as to what to remember may differ significantly across such different groups of actors as government planners, business operators, residents and visitors, and will always be open to the pressures of the marketplace (Hoelscher \& Alderman, 2004).

Cassia (1999, p. 297) writes that history as a scholarly activity is a means of producing knowledge about the past while heritage is a means of consuming that knowledge. Heritage 
sites are central to tourism activity not least because they constitute an important forum through which messages about national identity, values and beliefs are promoted. As Timothy and Boyd (2006, p. 3) state, heritage tourism is often used 'to build patriotism at the domestic level and spread propaganda to international visitors'. Tourists seeking to learn about the places that they visit understand that heritage sites, whether buildings, monuments or places, offer an opportunity to access and consume heritage that has been deemed to be important. If history is what a historian regards as worth recording and heritage is what contemporary society chooses to inherit and to pass on (Tunbridge \& Ashworth 2006, p. 6), then heritage sites are hugely important because they embody the selective representation of the past and officially make manifest the decisions that have been made about what is to be remembered. This is the case irrespective of what kind of heritage is at issue, whether landscapes, events, lifestyles or buildings (Harrison, 2004). When sites are obviously associated with difficult memories, for example, those commemorating battles, terrorism, colonial oppression and human atrocities, then the selection and representation of difficult memories pose particular challenges. Sites may be embarrassing to those sponsoring or participating in remembrance or to those being commemorated; they may be emotionally charged because of their association with casualties or other misfortunes; or they may be contested (Rivera, 2008, p. 613). This offers a dilemma as to what aspects of history should be remembered and what should be ignored, and how precisely sites should be represented and interpreted so as to portray the identities and images intended. Harrison $(2004$, p. 286) notes that

where heritage is involved, collective amnesia is common. What is remembered as tradition or heritage is selected from a vast range of built, natural and cultural environments, to celebrate the past and bolster the present. Shameful episodes are rarely given any prominence.

Those elements of the past that are chosen pass through a complex filtering process of selection by some individual or group (Harrison, 2004). Therefore, Harrison (2004, p. 287) contends, "what is considered "heritage" is continually subject to interpretation and reinterpretation, claim and counter claim, and negotiation'.

\subsection{Tour Guides as mediators}

It is into this contested realm that the Tour Guide enters, often as the key actor

entrusted with the public relations mission of encapsulating the essence of a place (Pond, 1993). Many ' $\ldots$.. places do not easily speak for themselves; some way must be found to enable the visitor to grasp what is seen in such a way that an informed freedom of interpretation is possible. (Brett, 1993, p. 187)

As already discussed, Cohen (1985, p. 15) argues that this mediation role is central to the work of the Guide who must translate 'the strangeness of a foreign culture into a cultural idiom familiar to the visitors'. This mediation process, as defined by Cohen (1985), involves the Guide selecting and de-selecting, highlighting and glossing over, inflating and downplaying, as well as interpreting the sites, elements and artefacts presented to the tourist.

When difficult memories are at issue, this process becomes more challenging. The problem with difficult heritage is that it fails to assert a positive sense of identity and 'is an inheritance that many might wish to disown even while they acknowledge it to be part of their defining history' (MacDonald, 2006, p. 127). Furthermore, she notes, 
where 'difficult heritage is addressed it is quite likely to be implicated in a range of quite complex and even conflicting emotions and responses' (MacDonald, 2006). The articulations of these difficult memories are contained within the narratives of guides who depict the past through interpretation and selectivity, in effect, acting as gatekeepers of memory. Beyond this, Guides are 'directors and stage-managers' who 'choreograph tourists' movements' (Edensor, 2001, p. 69). Their pivotal role is 'to influence visitors' impressions and attitudes, as well as to enhance their appreciation and understanding of their surroundings' (Gurung et al., 1996 cited in Dahles 2002, p. 787). They thus 'serve as a buffer' (Gurung et al., 1996, pp. 11-12 cited in Dahles, 2002, p. 787), offering 'preferred readings' (MacDonald, 2006, p. 123) and acting as highly effective instruments of control, controlling the contact between tourists and the host society as well as 'the images and narratives by means of which the host society presents itself ${ }_{i}$. ' (Dahles, 2002, p. 787).

Cohen's (1985) notion of the Guide as a mentor sees them selecting objects of interest according to their own preferences or taste, their professional training or what they assume is the interest of their party. Their 'interpretation ... can give tourists new insights and understandings of the area they visit and the culture and environment they experience', and these interpretations may be 'self-serving or conformist narratives' (Reisinger \& Steiner, 2006, pp. 483-484). In this way, Tour Guides have the opportunity for individual and individualised memory-making. Alternatively, Cohen explains, the Guide can act as a pathfinder, leading tourists through an environment in which they lack orientation, pointing out routes and attractions within a defined territory to which they have no access without the Guide. These 'guided tours assure that tourists are channelled into the right place at the right time, doing so under the control of someone responsible' (Dahles, 2002, p. 787).

A strong suggestion clearly running through this literature is that the Tour Guide is a very powerful individual, 'the central actor' (Edensor, 2000, p. 224), possessed of considerable autonomy and a great deal of license to mould the experiences of the tourists who come within their orbit. In contrast, the tourist is understood to play something of a passive role, reliant on the Tour Guide for knowledge and guidance, unquestioningly believing the information (or story) that is imparted (Overend, 2012) and developing understandings heavily shaped by 'the subjective and replicated interpretations of their Tour Guides' (McIntosh \& Prentice, 1999, p. 2).

This proposition, however, does not go unchallenged. Elsewhere in the tourism literature, Edensor and Holloway (2008) explain that 'different tourisms produce diverse, emergent rhythms' and while tourists 'can and do perform in accordance with norms that seek to territorialise agency' these performances are interactive and are always full of potential for multiple 'rhythms' that are varied and unfolding (Edensor \& Holloway, 2008, pp. 486 487). 'Rather than being fixed, performance is an interactive and contingent process' that 170 'succeeds according to the skill of the actors, the context in which it is performed, and the way in which it is interpreted by an audience' (Edensor, 2000, p. 324). Writing specifically about tour guiding, Salazar (2005) picks up this theme, identifying the process of guiding as interactive and something that cannot be fully controlled. He notes how despite the fact that the guided tours of the city of Yogyakarta, on the Indonesian island of Java, are 'professionally framed and manipulated by the guides', they are also determined by the tourists' demand for 'a commoditised, reductionist, touristic representation' of the village (Salazar, 2005, p. 641). Leonard (2011, p. 115) similarly negates any suggestion that 'tourists are passive recipients of the information they receive'. Holloway (1981, p. 389), very astutely, argues that "the guide while "an authority" is not "in authority", , and the performances at issue vary enormously depending on a number of factors, not least of which are the players and the relationship between the players involved (Edensor, 2001). 
Thus tourists can be construed as ' ... co-creators of the (content of) destination imaginaries' (Bryon, 2012, p. 30) and may form and inform the tour. As Larsen and Widtfeldt Meged (2013, pp. 89-90) suggest, Guides and tourists may be seen as 'mutual depending co-producers of the guided tour' where the role of the Guide is not to educate the tourist but rather to light the way (Reisinger \& Steiner, 2006). The potential influence that tourists can exert on a tour guiding setting can pose difficulties for the Guide, particularly in instances where they challenge the Guide's authority and knowledge, where they obviously do not listen and appear uninterested, or are disruptive in some way (Widtfeldt Meged, 2010). Indeed their impact can be such that they negotiate and contest the very frame of the tour (Widtfeldt Meged, 2010), block any attempt to sanitize the experience and demand a voice in its interpretation (Mowatt \& Chancellor, 2011). Edensor (1998) argues that individuals and small groups of tourists may negotiate the meanings of official narratives, resulting in the dominant versions being eschewed and replaced by subaltern and minor accounts.

Thus while historically there has tended to be an assumption that the production of tourism involves performances being enacted for tourists (Edensor, 2000), there is now a growing awareness that tourists have an ability to exert agency. In tour guiding settings, many questions remain to be answered about the nature of co-production. Edensor (2000) reminds us that on entering the tourism stage, tourists bring with them much cultural baggage in the guise of class, gender, ethnicity and other influences like inter-cultural relationships. In visiting the site, some may purely seek entertainment while others may seek to reclaim their heritage (Timothy \& Teye, 2004, cited in Mowatt \& Chancellor, 2011) or to confirm their personal identity and history (Mowatt \& Chancellor, 2011). In heritage settings such as the one under investigation here, the nature of the historical relationships between the visiting tourists and the host culture group is an important underlying context. Yet to date, relatively little is understood about how these factors inform tourist agency or create conditions under which tourists can intentionally or unintentionally sway, unsettle or disrupt dominant tour guiding narratives. This is a further focus for this research.

\subsection{Study site and methodology}

Developing heritage tourism has been a strategic priority for state tourism agencies in Ireland since the late 1980s. Despite this, the topic is relatively under-researched in the academic literature, although the development of visitor centres in protected areas during the 1990s and the controversies that these engendered has attracted attention (Healy \& McDonagh 2009; McGrath 1996; Moles, 1994). The representation of heritage and heritage landscapes has also been discussed (Johnson, 1999). However, many topics, including those addressed here, remain under-researched. Dublin Castle is an important heritage site that attracted 103,287 visitors in 2013 (Fáilte Ireland, 2013). It is state owned and managed, operated by the Office of Public Works (OPW). The political, economic and socio-cultural significance of Dublin Castle as a historical site cannot be overstated. Its origins date back to the foundation of the city by the Vikings in $842 \mathrm{AD}$, as it was here that the Viking invaders first established a settlement. Indeed, the city's name comes from the 'Dubh Linn' or the Black Pool of water that once covered what is now the Castle garden. When the AngloNorman invaders removed the Vikings as rulers in 1170, they developed this site into what was to become the administrative heart of British rule in Ireland for the 700-year period when Ireland was colonised by Britain. It was here that the British viceroy, head of the British administration in Ireland, resided. Equally it was the working heart of that 
administration, as well as being the headquarters of the Royal Irish Constabulary and the Dublin Metropolitan Police force. Located adjacent to the Castle in Ship Street was a military Barracks.

In the immediate aftermath of the 1916 nationalist rising, the Castle was used as a hospital for some of the wounded, including some of the nationalist leaders. When Ireland became a free state in 1922, it was here that the momentous transfer of power took place. Since then, the Castle has been in Irish state hands. Today, alongside its tourism role, it retains a number of key administrative functions. Those parts of the Castle now known as the state apartments are used for state business, while another substantial section houses a conference centre often used for state purposes.

In this context, the current research is interested to investigate how the complex and frequently contested political and social significance of Dublin Castle is captured in the tour guiding narratives given to visitors. The study adopts an interpretivist philosophy and employs two forms of data collection: covert participant observation and semi-structured interviewing. Using two methods to collect data was intended to ensure credibility and trustworthiness, and to enhance the quality of the research (Knafl \& Breitmaye, 1989).

Similar to an approach adopted by Tomazos and Butler (2012), covert participant observation was considered a suitable means of bringing the researchers unobtrusively close to both the tourists and the Tour Guides in a way that allowed them to take note and interpret the workings of the tour. At the outset, the researchers gained the permission from the OPW to carry out both the observation and the interviewing work. While the OPW was aware when the research project was ongoing, individual Tour Guides did not know when researchers took part in guided tours. Data collection began in spring 2011 with the participant observation which involved the researchers joining the tours thereby becoming fellowtourists, allowing them, as explained by Tucker (2005), to interact with and observe the Tour Guides as well as the tourists' performances in situ. This approach is described by Gold (1969, cited in Bowen, 2002) in his typology of participant observation as 'complete participation' and as employed in this research was a non-intrusive approach. It enabled the researchers to observe how the tour guiding narratives emerged and unfolded naturally over the course of a tour, ensuring that the tour was not created, manipulated or contaminated by the researchers (Bowen, 2002; Tomazos \& Butler, 2012).

Both researchers took an initial tour, made observations and notes independent of each other and then compared these as a form of control on how the data were being gathered. In addition, each researcher undertook three further tours each at different times and with different guides. On each tour, the researcher tried to identify and to read the narrative of the tour. This 'reading' entailed: noting the verbal detail and verbal emphases relayed as part of the dominant guiding narrative; noting the exchanges between Tour Guide and tour group members during the tours and between tour group members and noting the Guide's highlighting of particular places, material objects, artefacts and symbols throughout the tours. It also involved noting the behaviour and engagement of the visitor groups. The researchers wrote up detailed notes on the observation immediately after each tour, and the full set of notes were then analyzed to identify the degree of alignment/divergence in the storylines, and to thematically identify recurring emphases, absences and vignettes in the storylines.

This observation work was followed up with five semi-structured interviews with OPW personnel. At the time of the research, seven Guides were working in the Castle, and purposive sampling was used to select an Assistant Principal Officer (APO) who acted as Manager of a cluster of heritage sites in Dublin, including Dublin Castle; a Supervisory Guide was working in Dublin Castle and three other Guides. In the interviews with the Guides, the researchers explained that they had recently undertaken a number of guided tours of the 
Castle. The interviews were all approximately one hour in length. They were all recorded, transcribed verbatim and interpreted thematically to identify recurring themes with respect to inter alia how the Guides understood their roles, how they set about devising and delivering a 'script' to tourists and how they viewed the role of the tourist in the process. The data generated through the research interviews are quoted throughout the paper.

\subsection{Constructing the narrative}

Tour Guides are employed and trained by the OPW. According to the discussions with the APO, training Guides is an important activity but the focus is mainly on areas like health and safety, presentation (in terms of e.g. dress code) and visitor service (in terms of e.g. handling visitor questions, ensuring a comfortable tour, etc.). Little training is given in respect of how Guides prepare and present information about a site. According to the APO, when recruiting, the OPW seeks to employ people who are interested, knowledgeable and enthusiastic. Guides are expected to 'self-learn' the knowledge that they need in order to give a tour of a specific site like Dublin Castle. The OPW makes available a range of monographs, histories and guides to its sites and related topics and Supervisory Guides are expected to ensure that Guides use these to prepare for their guiding role.

While there are no systems in place to control or monitor the information that Guides give to visitors, as the APO explained, there are informal understandings of what is and is not appropriate: for example, the OPW does not encourage an overly 'academic' narrative. Equally, it promotes flexibility in delivery, acknowledging that different groups have different needs (e.g. youth, children, specialists) and believing that sensitivity to certain historical contexts and situations is required when working with particular types of visitors. Finally, it is expected that Guides set aside their own political views and be considerate to the varied sensitivities that may be associated with sites such as Dublin Castle. Thus, an early finding is that the Guides employed at the Castle are expected to demonstrate an understanding of the difficult memories that the site engenders, and to construct and deliver narratives that are sensitive to the complexities at issue.

Interviews with individual Guides confirmed that there are few, if any, formal guidelines or structures controlling how they develop and deliver a narrative, beyond such basics as a requirement to carry out a duty of care to the site itself, a requirement to keep the narrative to 45 minutes in duration and an implicit understanding that the key historical points (e.g. dates, events, personalities etc.) should be covered. As one Guide put it 'There's no script. You do the readings. You follow the other Guide, the more senior experienced Guide and then you're released and let go. That's it.' That having been said, according to another Guide 'there is a core story-line running through the tours and this does not change'. Participation in the tours confirmed this: all of the tours taken by the researchers had an overarching storyline that was broadly comparable. In essence, the storyline was fundamentally a tracing of the evolution of the Castle over time. All of the Guides began by synopsizing the historical evolution of the Castle over time and briefly tracing Ireland's 700-year colonization by England, up to its emergence as an independent state in the mid-twentieth century. From the outset of the tour, visitors are left in no doubt as to the immense political significance of the Castle.

\subsection{Interpreting and mediating the Castle's stories}

While all of the tours adhered to this basic storyline, and tended to most frequently dwell in the eighteenth and nineteenth centuries, there was considerable variation in the emphases 
attached to particular elements of the narrative. In effect, a number of storylines ran through the narratives with a recounting of the Castle's social significance being the most prevalent. The storylines are captured in Table 1. The findings show that at one extreme, they portray Georgian Dublin as glamorous, exciting and at the heart of all political and social action. In this context, the difficulties involved in retelling the story of how a country was colonized were handled quite differently by individual Guides. At one extreme was the Guide who jokingly portrayed England as the benevolent 'carer', with Ireland as the 'dependent' with naughty tendencies in need of reprimand. At the other extreme, visitors were given the merest hints of the tensions, conflicts and tragedies that have characterized the relationship between the two countries over time. In the middle were the Guides who downplayed the political aspects and instead emphasized more palatable aspects like societal habits and architectural features. From the observation work, it was clear that Guides tend to draw on individual areas of expertise/specialisms in constructing a narrative as Cohen (1985) suggests. Thus, those with an art history background tend to focus on the art collection, those with a background in architecture concentrate on the built features while both of these clearly differ from Guides whose interests lie in social history.

The political significance of Dublin Castle is such that it is associated with numerous potential sensitivities. In essence, it symbolizes an extensive period of Irish history when Ireland was oppressed by, and rebelling against, its colonizer England. The difficulties of remembering and retelling this history to outsiders (tourists) are compounded by the immensely close and complicated ties that have for centuries bound the two countries together. Not least of these is the fact that Ireland's largest overseas visitor market has long been the UK. According to Tourism Ireland Ltd., 54\% of overseas visitors to Ireland in 2011 were from the UKm. Fifty-two per cent of these visited Dublin (Tourism Ireland Limited, 2012). Thus, the matter of handling political sensitivities would seem to be very real.

340 As already discussed, the OPW is clear that Tour Guides in their work have a duty to be sensitive in how they deliver information about the Castle. When asked to talk about their roles and responsibilities as a Guide, the study participants were very conscious of the need to adopt a sensitive approach. They were very aware that sites such as the Castle can have

Table 1. Predominant storylines in the tour guiding narratives.

\begin{tabular}{ll}
\hline $\begin{array}{l}\text { Predominant Castle } \\
\text { storylines }\end{array}$ & \multicolumn{1}{c}{ Key features } \\
\hline Social significance & $\begin{array}{l}\text { Social meanings, roles and functions of: persons (residents and key } \\
\text { visitors); the Castle as venue ('society' events, e.g. balls, soirees, } \\
\text { dinners) and individual rooms (e.g. drawing room, dining room) } \\
\text { Value of Castle interior (fireplaces, plasterwork, furnishings, etc.); } \\
\text { connections with leading European artists/sculptors of the day (e.g. } \\
\text { influence of the French court at Versailles) }\end{array}$ \\
Home to the viceroy; visits from various monarchs; function and \\
embellishment of the Throne Room, (entwining of shamrocks, roses \\
and thistles on chandelier, etc.); symbolism of art work in St Patrick's \\
Hall power \\
$\begin{array}{c}\text { Its symbolic role in the transition of Ireland from colony into nation, } \\
\text { particularly the transfer of power in 1922; its association with James } \\
\text { Connolly, one of the leaders of the 1916 rising; its modern-day usage } \\
\text { for state ceremonial functions including the inauguration of Irish } \\
\text { Presidents }\end{array}$
\end{tabular}


very difficult memories, or as one Guide put it: 'charged histories'. Based on this, they proceeded with caution, conscious that visitors may be of different political persuasions. One Guide explained:

So you kind of, hmm, not that you wouldn't tell them everything but you'd just, you'd be careful how you'd phrase things.' ... 'Like we mention 1916, hmm, the Easter Rising and (how) James Connolly spent time in the Castle before his execution at Kilmainham but you'd never really ram it down people's throats if you know what I mean. I try and say it as matter of fact and as simply as possible and a lot of the time it's trying to pick words that don't sound too antagonistic'.

Another Guide spoke similarly about managing potential interactions that arise with visitors:

well kind of just give them the answer but don't go into detail or say that 'we'll discuss that later' ... because you wouldn't have the time anyway to be getting into a heated debate and plus you don't want to and you want to make everybody feel comfortable, you know. It's a group thing as well as an individual thing.

Equally, the Guides can downplay political aspects because they themselves do not feel comfortable. As one explained:

I kind of steer away from the overtly political ... I don't think I'm conversant enough with that part of history anyway to kind of open up a huge big dialogue about it ... I'd know the basics ... the dates and the events but I wouldn't feel comfortable

The researchers' experience of partaking in the tours supports the interview data. Certainly, the Castle's historical role was largely depoliticized by the Guides. Past political difficulties between Ireland and Britain were very much downplayed or at least spoken of in a very matter of fact tone, with one exception. In one of the tours, the Guide highlighted the story of James Connolly, one of the leaders of the 1916 Irish rising. Having been wounded during the conflict, Connolly had been taken to the Castle to be nursed and court-martialled by the British for treason. He was subsequently taken from here to be executed in nearby Kilmainham Gaol. The irony of Connolly having been nursed back to sufficient health to enable him to be transported for execution came through clearly in the Guide's narrative. The story of Connolly featured in two other tours: in one, the Guide related the story in humorous overtones with no attempt to put the story in the context of the 1916 Rising; in another, the story was told simply as a matter of fact.

The viceroy was another figure that featured prominently. In general, he was painted in neutral or even positive tones: one of the Guides made recurring references to the viceroy as a benevolent figure, explaining how a lot of viceroys bequeathed furniture and other artefacts to the state. At one point she characterized the viceroy as the British monarch's representative in Ireland whose task was to ensure that 'Ireland was behaving itself'. Later on, while interpreting a print showing a vice regal party leaving the Castle on horseback, overlooked by the heads of Irish people stuck on stakes emerging from the Castle walls, she jokingly explained that this was what happened when 'Irish people did not behave themselves'. In a similar vein, a highly symbolic painting displayed on the ceiling of the former ballroom (St Patrick's Hall) was interpreted in terms of its portrayal of Ireland being 'under the care of England'. Meanwhile, the creation of the Knights of St Patrick, whose colours drape the Hall, was explained by this same Guide as being 'a little boost' 
for Irish people. Another Guide, when questioned on the relationship between the Irish people and the viceroys, quickly glossed over the tensions that existed by explaining how each viceroy had a different relationship with the Irish people, some better than others. The one negative note struck in respect of a viceroy came from one particular Guide who explained that when leaving the Castle in 1922, the last viceroy had taken most of the furniture with him, thereby leaving the Castle relatively bare. All of these instances demonstrate the ability of individual Guides to subtly modify the messages portrayed through the narrative. As one Guide explained: 'there are some things that I wouldn't necessarily agree with what my colleagues say about particular things or its relevance to the tour and I just kind of ... leave that out or put something else in'.

The Guides interviewed spoke of having to cater for a variety of tourists. Some are very knowledgeable about Irish history, some have strongly held political views, while others have very little knowledge about the history in question and hold few pre-conceived views on what should or should not be remembered. Indeed, one Guide spoke about how efforts to be sensitive were sometimes unnecessary as 'we're more aware of these sensitivities than the general visitor is anyway ... it's even shocking how many Irish people don't know the history of their own country anyway and their own city'. Thus, for a Guide attempting to selectively re-tell a particular story, negotiating the tourist presence can be a challenge. This creates a difficulty for the Guide who runs the risk of overwhelming visitors with information that they are ill-prepared to absorb and equally of offending visitors by mentioning or failing to mention certain details. One Guide, for example, related how a lot of tourists complain about omissions in the narrative: 'Irish people would be like: you barely mentioned anything about like, you know, 1916 or Michael Collins and I say 'well Michael Collins didn't really spend an awful lot of time here.'

In a site with the charged history like that of the Castle, emotions can run high. As one Guide explained:

there are some horror stories that my colleagues have of people getting upset, shall we say, in the middle of a tour ... One gentleman (tourist) accused my colleague of being a member of the IRA and killing his brother so it left her in tears in the middle of the courtyard ....

In some cases, visitors' engagement with the Guide may be driven by their own agenda as reported by one Guide:

you might usually get maybe a Scottish person asking about 'oh I'm sure you were glad to get rid of the Anglo Irish' or something like that and you are aware that there's an English person within the group who ... Knows they should probably feel offended but they don't really know what they're feeling offended about. So I think as a Guide it's your job to kind of step in and lift that tension away

Guides also spoke about how, at other times, international visitors' impartial knowledge of Irish history might lead them to ask questions lacking in political correctness and unwittingly cause offence. In such cases, the Guide again must manage the situation, taking care that offence is minimised or eliminated. As one Guide explained: (If) you've got English people you don't want (them) ... to feel alienated or think you're going down this very Republican agenda which you're not doing.

Undoubtedly, the composition of the visitor group is a key factor. Given the particular historical context, the presence of visitors from the UK is an issue that Guides tend to be conscious of. As one Guide explained: 
British visitors, they're a tricky lot. And I find on the whole most of them are fantastically interested in it, and much more interested than offended. You do occasionally notice sometimes that they do kind of look to the floor when you're talking about something in particular. Most of them come up and kind of go 'God, I didn't realise that Britain had such an influence on Ireland' ... I suppose when they think of Ireland they think of Northern Ireland today as opposed to the other seven hundred odd years that came before that.

However when the group composition is more international, for example, continental Europeans and Asians, awareness of, and interest in the political importance of, the Castle can be very modest.

\subsection{Narrative as co-production}

There was a strong sense that the Guides understood that their role involved playing host. One Guide relished this task: "I like going in and saying "welcome" ... You know, bring them in, settle them down and they're now part of my journey. So I take them through the building.' Playing host requires conscious performance. As one Guide said, 'I consider it acting. You know, you get yourself ready, relax, prepare yourself and then go and talk and take it from there.' Yet it is equally clear, as suggested by Best (2012), that this is not a solo performance. The findings indicate ongoing dialogue and interchange between tour group and Tour Guide. As acknowledged by Leonard (2011) and Edensor and Holloway (2008) amongst others, far from being passive recipients of information, visitor audiences can engage and intentionally act in ways that influence the overall narrative production process. Most of the Guides interviewed showed themselves to be aware of, and open to, the idea of performing the narrative in tandem with the visitor. They spoke about consciously seeking to tailor their narrative to the particular group at issue. So one Guide, for example, tries to glean some information from groups so as to make connections through the narrative that she crafts. Another said that

something I've learnt and been practicing more in the last couple of years is to actually listen ... sometimes ... I forget people are on a day out and they're not necessarily looking for a lecture. They're looking for interaction and you know that people want to have their little say as well.

She invites questions and looks for cues as to what issues groups might be interested in. She further suggested that 'the narrative can change depending on questions that are thrown up by the public ... they're forming the narrative for you. You are responding to it'.

A different Guide tends to ask group members their nationalities so as to get a sense of who is in the group and how he might introduce some common points of reference into his narrative. However, he doesn't invite interaction: 'You just take them through and there's very few questions, Maybe in a way I do dominate my tour. ... I expect people to listen to me and that's me.' However, this approach was not prevalent. More commonly, the Guides reported the different ways in which tourists actively engage with them. One, for example, explained how Guides can learn from tour group members. While another related how he has gained a lot of knowledge from expert tourists like architects, art historians and other types of historians who come to visit the site because of their interest in some particular aspect of the building or its collections. Visitors to heritage sites increasingly access a wealth of information online. As noted by Widtfeldt Meged (2010), those who inform themselves may then question or challenge the Guide on various factual points. As one Guide explained: 'You get people challenging you about facts and then you get 
people challenging you about very, very silly things that really aren't even relevant to the tour.' Another Guide, meanwhile, spoke about a visitor (an Irish person) once rebuking him for a comment he made about the use of the Irish language and reminding him of the importance of using his guiding narrative to convey positive messages about the Irish language.

As suggested by Edensor (2001), the heterogeneity of visitors coming to the Castle was an important factor, with visitors actively engaging and making sense of the narratives from their own individual perspectives. All of the tours included in the observation work were given through English. This makes it difficult for non-native English speakers to engage with the Guide, much less challenge the kind of narrative being delivered. However, the observation work noted a distinct tendency for sub-groups travelling together to talk among themselves while the tour was ongoing. The in-group chatting was often picking up on a point of interest noted by one of the group and resulted in what Edensor and Holloway (2008) referred to as multiple rhythms occurring throughout the tour. Sometimes, it was a question of sharing understanding of what the Guide had just explained. As Widtfeldt Meged (2010) has noted, this kind of visitor activity can distract the Guide or upset other people who are trying to engage with the Guide. Occasionally, it seemed that the role of the Guide was quite unimportant, other than to physically guide tourists through the building, in the guise of Cohen's (1985) pathfinding role. In addition, for long-haul international visitors with little knowledge of Ireland's colonial past, the political import of the Castle seemed unimportant. The observation work noted few questions of a political nature; however, when these did emerge they tended to come from visitors with a strong interest in Irish politics. On one tour, for example, a US visitor persistently asked the Guide questions about the political situation in Northern Ireland. This questioning became quite disruptive, so while the tour moved between rooms the Guide took the visitor to one side and explained the situation out of earshot of the rest of the tour. In so doing, the Guide's action created 'a buffer' for the rest of the group (Gurung et al., 1996 cited in Dahles 2002) who seemed less interested in the politics of the situation, and simultaneously empowered the Guide to re-establish control over the narrative of the tour without further disruption.

More commonly, however, questions from the tour group were much more likely to relate to artistic or cultural matters (e.g. the function of a piece of furniture). Nevertheless, visitors could be observed to be actively making sense of the artefacts, storylines and events that feature in the tour narratives. Prior knowledge or understanding is not a prerequisite for active engagement. One of the Guides interviewed, for example, explained how Indian visitors to the Castle see certain parallels between Ireland's and India's historical colonial relationships with Britain. The Guide went on to explain that American visitors, meanwhile, tend to focus on the Castle's more recent history, especially the role that it played in the 1916 rising and in the handover of power from Britain to Ireland.

A variety of interest points can arise from the diversity within a tour group and this can, as suggested by Widtfeldt Meged (2010), significantly influence the tour guiding narratives that emerge during the period of the tour. Hence, as one Guide put it: 'you have to be very firm about sticking to your narrative in the Castle because you could be brought off on loads of different tangents and you haven't got the facility for that when you're bringing forty people around'. On a more physical level, and unintentionally, visitors can distract or disturb the narrative through their behaviour. Some of the Guides raised the issue of parents not managing their children while on the tour and other people getting annoyed in consequence. Guiding in busy sites like the Castle means a constant pressure to adhere to the allotted time available. As one Guide explained: 
you've got to engineer bringing that large group through the route of the tour and inevitably what happens if you don't keep it, you know, very well managed and short and sweet you'll have people, what we call trailers. So you're moving from one room into another and you've got a group trailing behind who are still standing in another room and you've got to bring them through.

This was certainly evident in the observation work. In one case, an Irish woman visiting with three children was at pains to explain to the children points that had been 'omitted' by the Guide. In this case, the objective was clearly to emphasize the political role of the Castle and to disparage very openly and quite loudly the British viceroys who, as rulers of Ireland in the past, had occupied the Castle. Clearly, the politically neutral tone of the narrative being offered did not satisfy the visitor and so she took it upon herself to supplement and colour the official narrative with her own interpretation. This overt type of resistance reflects Edensor's (1998) claim that individual tourists may negotiate the meanings of official narratives replacing them with 'more acceptable' accounts. The Guide in question did not appear to take any notice of this visitor's actions and simply kept on moving. The structure of the tour was sufficiently loose to enable this challenging of the dominant narrative take place on the margins.

\section{Conclusion}

Dos Santos's (2008) and Harrison's (2004) claim that particular power groups present the past in accordance with their present interests is apparent in the representation of Dublin Castle to its visitors. While the OPW takes a hands-off approach to the task of selecting which versions of the Castle's history are narrated, its active encouragement of a sensitive, flexible and non-academic storyline supports a decidedly neutralized and de-politicized narrative. Encouraged by the OPW to handle the charged history of the castle with sensitivity, individual guides showed conscious efforts to buffer visitors from discomfort or unease. Rather than 'forgetting to remember' (Devan \& Heng, 1994, p. 267), Guides at Dublin Castle seemed almost to 'remember to forget' or at the very least to neutralise the narrative in an effort to render it 'tidy and suitable' (Lowenthal, 1975, pp. 27-28) for their diverse audience.

However, while in general they followed a fairly standard narrative, the Guides had tremendous flexibility to interpret the story of the Castle in ways that were strongly informed by their own personal interests and backgrounds, in ways similar to those acknowledged by Cohen (1985) and Harrison (2004). This resulted in tours being overlaid with different "preferred readings' (MacDonald, 2006, p. 128). Thus, clearly, the Guides were not neutral, value-free agents. The extent of their agency was further manifest in the manner in which they were in a position to challenge the depoliticized narrative favoured by the OPW, by hinting at underlying political tensions and catching the attention of those tourists alert to the complexities encapsulated in the site. This was clear in the case of two of the narratives experienced by the researchers.

Yet while the data reveal the Guide to be a very powerful actor in reconstructing and re-imagining the heritage site under study, they do not support Dahles' (2002) description of guides as 'highly effective instruments of control'. Instead, they point to a myriad of ways in which tourists can both intentionally and unintentionally threaten the control exerted by the Tour Guide, challenge the shape of prevailing narratives and disrupt the selective remembering of particular histories. Intentional agency seems to require the tourist to have a degree of power and ability to unsettle/alter the tone being set by 
the Guide. Knowledge is an important source of empowerment that can be used to variously negotiate, reinforce or contest aspects of the prevailing narrative. Tourists can, for example, draw on technical knowledge (e.g. accuracy of historical dates) to challenge a point. They can draw upon their awareness of or allegiance to particular historical/political beliefs and perspectives. For some tourists, both personal and national senses of identity become heightened as they absorb and experience heritage sites which represent and symbolize issues of importance. This can lead to sometimes passionate and emotional engagement as people variously feel offended, angry, saddened, proud or amused by the stance adopted by the Tour Guide or by the intervention of a fellow-tourist in the course of a tour. As MacDonald (2006) has noted, interactions in places of difficult heritage inspire complex emotions and responses, and this was found to be the case here. For most visitors, the largely depoliticized narratives preferred by the Guides was accepted unquestioningly, perhaps, because they had little knowledge of, or were disinterested in, the country's colonial legacy, or because they could not fully grasp what the Guide was saying. However, the observation work revealed evidence of how some visitors quite openly challenge the Guide's narrative. Edensor (1998) and Mowatt and Chancellor (2011) noted how individuals and groups of tourists may demand a voice in interpreting and negotiating the meanings of official narratives, resulting in the dominant versions being eschewed and replaced by subaltern and minor accounts. Here, this was apparent in tourists asking political questions. In other instances, visitors drew on their own knowledge and perspectives to alter/expand the dominant narrative.

In summary, the findings of this study emphasize the important role that contemporary tourist sites and encounters play in continuously re-working and re-inventing memories and point to the complexities at issue in representing difficult memories. Trying to deliberately convey particular messages while simultaneously closing off other possible lines of interpretation (Lennon \& Foley, 2000, p. 162) may be a central aim of heritage site managers. However, their task is readily thwarted by tourist agency in ways that are not easily anticipated, especially in a site like Dublin Castle where the complexities of the memories at issue may only become apparent during the visit. This study suggests that the site managers, Tour Guides and tourists inter-connecting in the study site all bring different interests, motives and expectations to bear on the encounter. The entanglement of past and present, values and beliefs, expectations and requirements that ensue is extremely complex. While the Tour Guide has a substantial influence on shaping the memories that emerge through the Guided Tour, narratives shift according to a number of factors, nor least of which are the intentional and unintentional interventions of the tourist. While the findings reported here offer some insight into explaining how and why tourists become actively involved in shaping the Guiding narrative, this is a topic in need of further research.

Above all, the study's findings point to the fluid, constantly shifting and unpredictable nature of guiding narratives. While the tours did share a common theme, no two were alike, for reasons that related to the Guide, to the composition of the tour group and to the interaction between all of those participating in any given tour. The findings suggest that as the Guiding narrative unfolds, it can produce unsettling and unexpected effects on tourists, perhaps causing them to reflect on their own personal and collective memories, prompting them to adopt offensive or defensive positions, or reminding them of other kinds of memories. It was clear that for some tourists, the memories evoked were highly emotive and sometimes prompted them to intervene and impact on the Guiding narrative. For this reason, the affective dimensions of tourist encounters with heritage sites would seem to be a line of enquiry that offers much scope for further enquiry.

Undoubtedly, tourist agency complicates the task of the Tour Guide, making it significantly more difficult to portray a sense of the site in a way that fulfils the accommodating, 
mediating roles normatively expected of them. It equally complicates the task of the heritage site manager. Rather than a performance that is enacted for tourists (Edensor, 2000), these tours are co-produced and intermingled with multiple meanings. While this paper has gone some way towards understanding the intricacies involved, it remains an area worthy of continued investigation.

\section{Disclosure statement}

No potential conflict of interest was reported by the authors.

\section{References}

Alderman, D. H. (2010). Surrogation and the politics of remembering slavery in Savannah, Georgia (USA). Journal of Historical Geography, 36, 90-101.

Best, K. (2012). Making museum tours better: Understanding what a guided tour really is and what a tour guide really does. Museum Management and Curatorship, 27(1), 35-52.

Bowen, D. (2002). Research through participant observation in tourism: A creative solution to the measurement of consumer satisfaction/dissatisfaction (CS/D) among tourists. Journal of Travel Research, 41(4), 4-14.

Brett, D. (1993). The construction of heritage. In B. O'Connor \& M. Cronin (Eds.), Tourism in Ireland: A critical analysis (pp. 183-202). Cork: Cork University Press.

Bryon, J. (2012). Tour guides as storytellers - from selling to sharing. Scandinavian Journal of Hospitality and Tourism, 12(1), 27-43.

Chang, T. C., \& Huang, S. (2005). Recreating place, replacing memory: Creative destruction at the Singapore River. Asia Pacific Viewpoint, 46(3), 267-280.

Cohen, E. (1985). The tourist guide: The origins, structure and dynamics of a role. Annals of Tourism Research, 12(1), 5-29.

Dahles, H. (2002). The politics of tour guiding: Image management in Indonesia. Annals of Tourism Research, 29(3), 783-800.

Devan, J., \& Heng, G. (1994). A minimum working hypotheses for Singapore. In D. de Cunha (Ed.), Debating Singapore: Reflective essays (pp. 22-26). Singapore: Institute of Southeast Asian Studies.

Dos Santos, M. S. (2008). The repressed memory of Brazilian slavery. International Journal of Cultural Studies, 11(2), 157-175.

Edensor, T. (2000). Staging tourism: Tourists as performers. Annals of Tourism Research, 27(2), $322-344$.

Edensor, T. (2001). Performing tourism, staging tourism: (Re)Producing tourist space and practice. Tourists Studies, 1(1), 59-81.

Edensor, T., \& Holloway, J. (2008). Rhythmanalysing the coach tour: The ring of Kerry, Ireland. Transactions of the Institute of British Geographers, 33(4), 483-501.

Fáilte Ireland. (2013). Fáilte Ireland Dublin. Retrieved from http://www.failteireland.ie/FailteIreland/ media/WebsiteStructure/Documents/3_Research_Insights/1_Sectoral_SurveysReports/Failte_ Ireland_visitors_to_top_fee_charging_attractions_2013.pdf? ext=.pdf

Harrison, D. (2004). Contested narratives in the domain of world heritage. Current Issues in Tourism, $7(4-5), 281-290$.

Healy, N., \& McDonagh, J. (2009). Commodification and conflict: What can the Irish approach to protected area management tell us? Society and Natural Resources, 22, 381-391.

Hewison, R. (1989). Heritage: An interpretation. In D. Uzzell (Ed.), Heritage interpretation: Volume 1. The natural and built environment (pp. 15-23). London: Belhaven.

Hoelscher, S., \& Alderman, D. H. (2004). Memory and place: Geographies of a critical relationship. Social \& Cultural Geography, 5(3), 347-355.

Holloway, J. C. (1981). The guided tour a sociological approach. Annals of Tourism Research, 8(3), $377-402$.

Johnson, N. (1999). Framing the past: Time, space and the politics of Heritage tourism in Ireland. Political Geography, 18(2), 187-207. 
Knafl, K., \& Breitmaye, B. J. (1989). Triangulation in qualitative research: Issues of conceptual clarity \& purpose. In J. Morse (Ed.), Qualitative nursing research a contemporary dialogue. Rockville, MD: Aspen.

Larsen, J., \& Widtfeldt Meged, J. (2013). Tourists co-producing guided tours. Scandinavian Journal of Hospitality and Tourism, 13(2), 88-102.

Lennon, J., \& Foley, M. (2000). Dark tourism: The attraction of death and disaster. London: Continuum.

Leonard, M. (2011). A tale of two cities: 'Authentic' tourism in Belfast. Irish Journal of Sociology, $19(2), 111-26$.

MacDonald (2006). Mediating heritage: Tour guides at the former Nazi party rally grounds, Nuremberg. Tourist Studies, 6(2), 119-138.

McBride, I. (Ed.). (2001). History and memory in modern Ireland. Cambridge: Cambridge University Press.

McGrath, B. (1996). Environmentalism and property rights: The Mullaghmore interpretative centre dispute. Irish Journal of Sociology, 6, 25-47.

McIntosh, A., \& Prentice, R. (1999). Affirming authenticity: Consuming cultural heritage. Annals of Tourism Research, 26(4), 589-612.

Moles, R. (1994, May). Should the Burren interpretative centre be completed? An exploration of some of the issues. Geonews, 34, 14-23.

Mowatt, R. A., \& Chancellor, C. H. (2011). Visiting death and life. Dark tourism and slave castles. Annals of Tourism Research, 38(4), 1410-1434.

Overend, D. (2012). Performing sites: Illusion and authenticity in the spatial stories of the guided tour. Scandinavian Journal of Hospitality and Tourism, 12(1), 44-54.

Pond, K. (1993). The professional guide: Dynamics of tour guiding. New York: Van Nostrand Reinhold.

Reisinger, Y., \& Steiner, C. (2006). Reconceptualising interpretation: The role of tour guides in authentic tourism. Current Issues in Tourism, 9(6), 481-498.

Rivera, L. A. (2008). Managing 'spoiled' national identity: War, tourism, and memory in Croatia. American Sociological Review, 73, 613-634.

Said, E. W. (2000). Invention, memory \& place. Critical Inquiry, 26(2), 175-192.

Salazar, N. B. (2005). Tourism \& glocalization, 'local' tour guiding. Annals of Tourism Research, $32(3), 628-646$.

Timothy, D., \& Boyd, S. (2006). Heritage tourism in the 21 st century: Valued traditions and new perspectives. Journal of Heritage Tourism, 1(1), 1-16.

Tomazos, K., \& Butler, R. (2012). Volunteer tourists in the field: A question of balance? Tourism Management, 33(1), 177-187.

Tourism Ireland Limited (2012). GB market profile. Dublin: Tourism Ireland Limited. Retrieved from http://www.tourismireland.com/CMSPages/GetFile.aspx?guid=1ef39294-bd2a-4eb4-80c9-05cb $113 \mathrm{e} 47 \mathrm{~b} 5$.

Tucker, H. (2005). Narratives of place and self: Differing experiences of package coach tours in New Zealand. Tourist Studies, 5, 267-282.

Widtfeldt Meged, J. (2010). The guided tour - a co-produced tourism performance (Unpublished Thesis). Retrieved from http://rudar.ruc.dk/bitstream/1800/5912/5/1.phd_Jane_Widtfelt_Megad $\% 2882179 \% 29$ small_\%5B1\%5D.pdf

Zuelow, E. G. E. (2009). Making Ireland Irish: Tourism and national identity since the Irish civil war. Syracuse, NY: Syracuse University Press. 